\title{
Pengaruh Pembelajaran Demokratik dengan Pendekatan Saintifik Terhadap Hasil Belajar Siswa IPA SMP Negeri 1 Dumoga
}

\author{
I Wayan Arsana Putra ${ }^{*}$, Metilistina Sasinggala ${ }^{2}$ \\ 1,2 Jurusan Pendidikan IPA, FMIPA, Universitas Negeri Manado \\ *e-mail: iwayanarsanap@gmail.com
}

\begin{abstract}
Abstrak. Model pembelajaran demokratik merupakan model pembelajaran yang efektif karena siswa dapat berperan aktif dalam kegiatan pembelajaran. Penelitian ini dilakukan untuk mengkaji apakah terdapat pengaruh pembelajaran demokratik dengan pendekatan saintifik terhadap hasil belajar siswa pada materi suhu dan perubahannya. Subyek penelitian ini adalah siswa kelas VIIA sebagai kelas eksperimen yang diajarkan dengan menggunakan pembelajaran demokratik dengan pendekatan saintifik dan siswa kelas VIIB sebagai kelas control yang diajarkan dengan menggunakan model pembelajaran konvensional pada SMP Negeri 1 dumoga. Penelitian ini menggunakan metode eksperimen semu dengan menggunakan model rancangan two group, pretest postest design. Hasil penelitian menunjukan nilai rata-rata posttest pada kelas eksperimen yaitu 86,80 sedangkan pada kelas kontrol nilai rata-rata posttest yaitu 57,0. Setelah di uji statistik melalui uji-t, hasil belajar siswa kelas eksperimen dan kelas kontrol pada taraf nyata, $a=0,05$ diperoleh thitung $=4,16$ dan tabel $=1,67$. Jadi, thitung $=$ $4,16>t_{\text {tabel }}=1,67$, yang artinya statistik uji tersebut jatuh dalam wilayah kritiknya, maka tidak cukup bukti untuk menolak $\mathrm{H}_{\mathrm{a}}$. Dapat disimpulkan bahwa terdapat pengaruh pembelajaran demokratik dengan pendekatan saintifik terhadap hasil belajar IPA.
\end{abstract}

Kata kunci: pembelajaran demokratik, pendekatan saintifik, hasil belajar, suhu

Abstract. Democratic learning model is an effective learning model because students can play an active role in learning activities. This research was conducted to examine whether there is an influence of democratic learning with a scientific approach to student learning outcomes on the material temperature and its changes. The subjects of this study were students of class VIIA as an experimental class taught by using democratic learning with a scientific approach and students of class VIIB as a control class taught using conventional learning models at SMP Negeri 1 Dumoga. This research uses quasiexperimental method by using a two group design model, pretest posttest design. The results showed the average value of the posttest in the experimental class was 86.80 while in the control class the average value of the posttest was 57.0. After being tested statistically through the t-test, the learning outcomes of the experimental class and control class students were at the real level, $a=0.05$ obtained by $t_{\text {count }}=4.16$ and table $=$ 1.67. So, $t_{\text {count }}=4.16>t_{\text {table }}=1.67$, which means the test statistics fall within the area of criticism, then there is not enough evidence to reject $H_{a}$. It can be concluded that there is an influence of democratic learning with a scientific approach to science learning outcomes.

Keywords: democratic learning, scientific approach, learning outcomes, temperature 


\section{PENDAHULUAN}

Demokratik adalah model panyajian pelajaran dengan memeragakan dan menunjukkan kepada siswa tetang suatu proses, situasi atau benda tertentu, baik sebenarnya atau hanya sekedar tiruan. Terlepas dari metode penyajian tidak terlepas dari penjelasan guru. Walau dalam metode demonstrasi siswa haya sekedar memperhatikan (Ahmad dkk. ,2009).

Demokratis

merupakan pembelajaran yang menggunakan peragaan untuk memperjelas atau pengertian atau untuk memperlihatkan bagaimana melakukan sesuatu kepada peserta lain. Demonstrasi merupakan metode pembelajaran yang efektif, karena peserta didik dapat mengetahui secara langsung penerapan materi tersebut dalam kehidupan sehari-hari (Huda., 2013).

Pembelajaran demokrtik adalah penyajian bahan pelajaran dengan memperagakan atau mempertunjukkan kepada peserta didik suatu proses, situasi atau benda tertentu yang sedang dipelajari baik sebenarnya ataupun tiruan yang sering disertai penjelasan lisan (Syaiful dkk, 2000).

Dalam pembelajaran berbasis demokrasi, sistem pembelajaran ditekankan pada kegiatan yang melibatkan semua siswa dengan menekankan cara berpikir kreatif, kritis, dalam mengemukakan pendapat, ide, maupun gagasan sesuai dengan gaya belajar yang dimiliki dan beragam kecerdasan siswa yang meliputi kecerdasan verbal, matematik, ruang, kinestetik, musical, kecakapan intrapsikis ( Keren, 2011).

Pendekatan saintifik adalah suatu proses pembelajaran yang dirancang supaya peserta didik secara aktif mengkonstruk konsep, hukum, atau prinsip melalui kegiatan mengamati, merumuskan mengajukan/merumuskan hipotesis, mengumpulkan data dengan berbagai teknik, menganalisis data, menarik kesimpulan, dan mengkomunikasikan (Hosnan,2014).
Pendekatan saintifik merupakan pendekatan pembelajaran yang memberikan kesempatan pada siswa secara luas untuk melakukan eksplorasi dan elaborasi materi yang dipelajari, di samping itu memberikan kesempatan pada peserta didik untuk mengaktualisasikan kemampuan melalui kegiatan pembelajaran yang dirancang oleh guru (Rusman,2015).

Pembelajaran dengan pendekatan saintifik adalah prosespembelajaran yang dirancang sedemikian rupa agar peserta didiksecara aktif mengkonstruksi konsep, hukum atau prinsip melaluitahapantahapan mengamati (untuk mengidentifikasi dan menemukan masalah), merumuskan masalah, mangajukan atau merumuskan hipotesis, mengumpulkan data dengan berbagai teknik, menganalisis data, menarik kesimpulan dan mengomunikasikan konsep, hukum atau prinsip yang ditemukan (Daryanto, 2014).

Pendekatan saintifik dimaksudkan untuk memberikan pemahaman kepada peserta didik dalam mengenal, memahami berbagai materi menggunakan pendekatan ilmiah, bahwa informasi bisa berasal dari mana saja, kapan saja, tidak bergantung pada informasi searah dari guru.

Dari beberapa pengertian diatas dapat disimpulkan bahwa pembelajaran pendekatan saintifik adalah pembelajaran yang dirancang sedemikian rupa untuk mempermudah peserta didik dalam memahami berbagai materi yang diajarkan, pembelajaran saintifik ini melibatkan keterampilan proses seperti mengamati, mengklasifikasi, mengukur, meramalkan, menjelaskan, dan menyimpulkan.

Hasil belajar merupakan kemampuan yang diperoleh individu setelah proses belajar berlangsung, yang dapat memberikan perubahan tingkah laku baik pengetahuan, pemahaman, sikap dan keterampilan siswa sehingga menjadi lebih baik dari sebelumnya (Ngalim, 2002).

Hasil belajar merupakan salah satu indikator dari proses belajar. Hasil belajar adalah perubahan perilaku yang 
diperoleh siswa setelah mengalami aktivitas belajar

(Chatarina, 2004).

Dapat dipahami bahwa yang dimaksud dengan hasil belajar merupakan suatu proses untuk melihat sejauh mana siswa dapat menguasai pembelajaran setelah mengikuti kegiatan proses belajar mengajar, atau keberhasilan yang dicapai seorang peserta didik setelah mengikuti kegiatan pembelajaran yang ditandai dengan bentuk angka, huruf, atau simbol tertentu yang disepakati oleh pihak penyelenggara pendidikan. (Dimyati \& Mudjiono,2006).

Dari beberapa teori di atas tentang pengertian hasil belajar, maka hasil belajar yang dimaksud dalam penelitian ini adalah hasil belajar (perubahan tingkah laku: kognitif, afektif dan psikomotorik) setelah selesai melaksanakan proses pembelajaran dengan strategi pembelajaran information search dan metode resitasi yang dibuktikan dengan hasil evaluasi berupa nilai.

Berdasarkan penelitian Eksperimen yang dilaksanakan di SMP Negeri 1 Dumoga, dengan memberikan perlakuan pembelajaran demokratik dengan pendekatan saintifik memberikan pengaruh terhadap hasil belajar siswa dikarenakan pembelajaran demokratik dengan pendekatan saintifik Membuat guru memiliki keterampilan membuat RPP, dan menerapkan pendekatan saintifik secara benar, Materi pembelajaran berbasis pada fakta atau fenomena yang dapat di jelaskan dengan logika atau penalaran tertentu, bukan sebatas kira-kira, khayalan, atau dogeng semata serta Mendorong dan menginspirasi siswa secara kritis, analistis, dan tepat dalam mengidentifikasi, memahami, memecahkan masalah, dan mengaplikasikan materi pembelajaran. Selain itu juga sebagai hasil dari peran guru dalam menciptakan suasana kegiatan belajar yang sedemikian rupa, sehingga interaksi belajar mengajar berlangsung secara efektif.

\section{METODE PENELITIAN}

Penelitian ini dilaksanakan di SMP Negeri 1 Dumoga. Waktu penelitian dilaksanakan pada bulan November 2018. Populasi dalam penelitian ini adalah seluruh siswa kelas VII SMP Negeri 1 Dumoga tahun pelajaran 2018/2019 dengan jumlah 110 siswa.

Sampel dari penelitian ini adalah dua kelas yaitu kelas VII A sebagai kelas eksperimen dengan jumlah 25 siswa dan kelas VII B sebagai kelas kontrol dengan jumlah 25 siswa.

Rancangan penelitian yang digunakan adalah two group, pretest posttest design. untuk lebih lengkap dapat dilihat pada Tabel 1.

Tabel 1. Desain penelitian

\begin{tabular}{llll}
\hline Kelas & Pretest & Perlakuan & Posttest \\
\hline $\mathrm{A}$ & $\mathrm{T}_{1}$ & $\mathrm{X}$ & $\mathrm{T}_{2}$ \\
$\mathrm{~B}$ & $\mathrm{~T}_{1}$ & - & $\mathrm{T}_{2}$ \\
\hline
\end{tabular}

Penelitian ini terdapat dua variabel, yakni: variabel bebas adalah model pembelajaran demokratik diberikan pada kelas eksperimen dan model pembelajaran konvesional diberikan pada kelas kontrol. Variabel terikat adalah skor pretest dan skor postest siswa dalam mata pelajaran IPA di SMP Negeri 1 Dumoga.

Prosedur dalam penelitian ini yaitu menentukan sampel berupa kelas dari populasi yang tersedia dengan pertimbangan atas wali kelas atau kepala sekolah sebagai kelas eksperimen. Kemudian menyusun rancangan pembelajaran yang akan digunakan selama proses belajar mengajar pada kelas eksperimen dan kelas kontrol. selanjutnya menyusun instrument penelitian berupa tes hasil belajar. Kemudian memberikan tes awal (pretest) untuk kelas eksperimen dan kelas kontrol. memberikan perlakuan (treatment) kepada kelas eksperimen dan kelas kontrol. Setelah itu, memberikan tes akhir (posttest) dengan menggunakan model pembelajaran demokratik untuk kelas eksperimen dan model pembelajaran konvesional untuk kelas kontrol. Terakhir, menganalisis data hasil penelitian dan melakukan uji hipotesis. 
Tahapan dalam melaksanakan uji instrumen adalah uji validitas dan uji reliabilitas. Tahap ini bertujuan agar terdapat kesesuaian antara materi pelajaran yang telah diajarkan dengan instrumen yang telah dibuat sehingga data yang dihasilkan lebih akurat.

\section{HASIL DAN PEMBAHASAN}

Penelitian telah dilakukan di SMP N 1 Dumoga pada siswa kelas VII A sebagai kelas eksperimen dan kelas VII B sebagai kelas kontrol pada tahun ajaran 2018. Dimana jumlah siwa pada kelas masing-masing berjumlah 25 siswa. Data yang diambil merupakan data hasil belajar siswa pada mata pelajaran IPA khususnya pada pokok bahasan suhu dan perubahannya dengan ringkasan data dapat dilihat pada tabel 2 dan 3 .

Tabel 2. Hasil pretest dan posttest kelas eksperimen

\begin{tabular}{lll}
\hline Statistik & Pretest & Posttest \\
\hline Skor minimum & 20 & 75 \\
Skor maksimum & 55 & 95 \\
Jumlah $(\Sigma)$ & 760 & 2170 \\
Rata-rata & 30.4 & 86.8 \\
Standar deviasi (s) & 9.429 & 6.751 \\
Varians (S $\left.{ }^{2}\right)$ & 88.917 & 45.583 \\
\hline
\end{tabular}

Tabel 3. Hasil pretest dan posttest kelas kontrol

\begin{tabular}{lll}
\hline Statistik & Pretest & Posttest \\
\hline Skor minimum & 15 & 40 \\
Skor maksimum & 45 & 70 \\
Jumlah $(\Sigma)$ & 692 & 1425 \\
Rata-rata & 27.6 & 857 \\
Standar deviasi (s) & 8.163 & 49.242 \\
Varians (S $\left.{ }^{2}\right)$ & 6.643 & 85.416 \\
\hline
\end{tabular}

Hasil uji normalitas skor tes akhir pada kelas eksperimen menunjukan nilai $\mathrm{L}_{\text {hitung }}=0,120$. Karena Lhitung $(0,120)<$ Ltabel (0,173), maka data pada kelas eksperimen berdistribusi normal. Untuk uji normalitas skor tes akhir kelas kontrol menunjukan nilai $L_{\text {hitung }}=0,148$. Karena $\mathrm{L}_{\text {hitung }}=0,148<\mathrm{L}_{\text {tabel }}=0,173$ maka data pada kelas kontrol berdistribusi normal.

Hasil analisis pengujian homogenitas dilakukan pada data tes akhir. Berdasarkan hasil pengujian pada data tes akhir dengan $\mathrm{S}_{1}{ }^{2}=86,8$, dan $\mathrm{S}_{1}{ }^{2}$ $=57,0$ diperoleh nilai $\mathrm{F}_{\text {hitung }}=1,52$, sedangkan $\mathrm{F}_{\text {tabel }}=1,98$. Hal ini juga menunjukan bahwa $1,52<\mathrm{F}_{\text {tabel }} 1,98$ sehingga diputuskan bahwa diterima. Jadi, dapat disimpulkan bahwa varians dari ke dua kelas yaitu kelas eksperimen dan kelas kontrol tersebut adalah homogen.

Oleh karena uji normalitas dan uji homogenitas telah terpenuhi, maka statistik uji-t dapat dilanjutkan.

$$
\begin{aligned}
& \mathrm{H}_{o}: \mu_{1} \leq \mu_{2} \\
& \mathrm{H}_{a}: \mu_{1}>\mu_{2}
\end{aligned}
$$

Dengan, $\mu_{1}$ adalah nilai rata-rata hasil belajar kelas eksperimen dan $\mu_{2}$ adalah nilai rata-rata hasil belajar kelas kontrol. Dari hasil pengujian hipotesis dengan uji-t, pada taraf nyata $(\alpha)=0,05$ diperoleh $\mathrm{t}_{\text {tabel }}=1,67$, dan $\mathrm{t}_{\text {hitung }}=4,16$. Karena thitung $=4,16>t_{\text {tabel }}=1,67$ maka tolak $\mathrm{H}_{o}$ dan terima $\mathrm{H}_{a}$ yaitu $\mu_{1}>\mu_{2}$. Hal ini berarti bahwa rata-rata hasil belajar siswa yang diajarkan dengan menggunakan pembelajaran demokratik dengan pendekatan saintifik lebih tinggi dari pada rata-rata hasil belajar siswa yang diajarkan dengan mengggunakan model pembelajaran konvensional.

\section{KESIMPULAN}

Berdasarkan hasil penelitian dan pembahasan tentang pelaksanaan Pembelajaran Demokratik Dengan Pendekatan Saintifik Terhadap Hasil Belajar IPA yang dilaksanakan di SMP Negeri 1 Dumoga, maka dapat diambil kesimpulan yaitu Pengaruh Pembelajaran Demokratik Dengan Pendekatan Saintifik pada pembelajaran IPA di kelas VII mempunyai pengaruh positif terhadap belajar siswa dibandingkan dengan pembelajaran menggunakan metode konvensional atau ceramah.

\section{DAFTAR PUSTAKA}

Ahmad M. N \& Kholidah L. N, dkk. (2009). Metode dan Tehnik Pembelaaran Agama Islam. Bandung: PT Refika Aditama.

Catharina, dkk. (2004). Psikologi Belajar. Semarang: IKIP Semarang Press.

Daryanto, dkk. (2014). Pendekatan pembelajaran saintifik kurikulum 2013. Yogyakarta: Gava Media. 
Dimyati \& Mudjiono, dkk. (2006). Belajar dan Pembelajaran. Jakarta: Rineka Cipta.

Hosnan M., dkk. (2014). Pendekatan saintifik dan kontekstual. Bogor: ghalia Indonesia

Huda, dkk. (2013). Model-Model Pengajaran dan Pembelajaran. Yogyakarta: Pustaka Belajar.

Ngalim, dkk. (2002). Psikologi Pendidikan. Bandung: Remaja Rosda Karya.

Rusman, dkk. (2015). Pendekatan Saintifik. Jakarta : Bumi Aksara

Syaiful, D. B., dkk. (2000). Strategi Belajar Mengajar, Jakarta: Rineka Cipta.

Yusri M., dkk. (2011). Pembelajaran

Demokrasi. Jakarta: PT. Rineka Cipta 